\title{
Practicality and Effectiveness Test of Graphic Design Learning Media Based on Android
}

\author{
https://doi.org/10.3991/ijim.v14i04.12737 \\ Asrul Huda ${ }^{(凶)}$, Nelda Azhar, Almasri, Khairul Anshari \\ Universitas Negeri Padang, Padang, Indonesia \\ asrulhuda@gmail.com \\ Suryo Hartanto \\ Universitas Riau Kepulauan, Batam, Indonesia
}

\begin{abstract}
Based on preliminary observations on the implementation of Graphic Design learning, it is indicated that it is only limited to using printed module media, lecture methods, guided practice and not yet using media with android technology. This study aims to: (1) Generate a practical learning media for Graphic Design based on Android Technology. (2) Producing Learning Media Graphic Design based on Effective Android Technology. This research is a Research and Development. This study uses a study design development with 4D development model that consists of four main stages, namely, Define (definition), Design (design), Develop (development), and Disseminate (deployment). Based on the practicality test, the practicality test value was $85 \%$. Effectiveness Test of learning media for Android-based Graphic Design shows effective results, this is also shown with a significant level of $0,000<0.05$, which means that there are significant differences between Student Learning Outcomes before being given an Android-based media (Pretest) and learning outcomes students after being given an Android-based media ( Posttest ) in the Informatics Engineering Education Study Program, Faculty of Engineering, State University of Padang
\end{abstract}

Keywords-Learning Media Graphic Design, Practicality Test, Test Effectiveness, Android Technology

\section{Introduction}

Based on a report released by UNESCO every year and containing the results of world education monitoring, from 120 countries, Indonesia's Education Development Index (EDI) is in 64th position. Survey results of the PERC (Political and Economic Risk Consultancy) and UNDP (United Nations Development Program). PERC stated that the Education system in Indonesia occupies the worst position in the Asian region. South Korea is considered to have the best education system, followed by Singapore, Japan, Taiwan, India, China and Malaysia. Indonesia ranks 12th, it is one level below Vietnam. This shows that the quality of education in Indonesia is still relatively low. 
Besides education also plays a role in producing human resources and shape humans so they can play a role in their lives [1].

Based on the syllabus of Graphic Design Courses in the Electronic Engineering Department and the results of discussions with lecturers supporting the Graphic Design Course at the Electronic Engineering Department on July 6, 2015, obtained information about the learning of Graphic Design which is contained in the Syllabus. In the syllabus, it is stated that lecturers use various kinds of learning methods namely: lecture, discussion, presentation, practicum (guided practice) methods. The choice of method is based on the level of difficulty of the material to be discussed.

The results of the discussion, it was revealed that lecturers had difficulty in delivering student practice material due to the limited time available in the implementation of the learning process. In completing practice students find it difficult because they have to wait for instructions / direction from lecturers supporting the course. In general, learning takes place conventionally, with the lecturer as the center of learning. The unavailability of complete learning tools also causes difficulties for students and lecturers in conducting the teaching and learning process. The average scores obtained by students are as follows: $15.46 \%$ get an A, $18.56 \%$ get a B, $46.39 \%$ get a C, $13.40 \%$ get a $\mathrm{D}$, and $6.19 \%$ get an E. value shows that only $34.02 \%$ received an A and a B. This means that changes made to Graphic Design learning have not been able to improve student learning outcomes for the better.

Based on preliminary research on the objectives and learning content of Graphic design, it can be concluded that the objectives of the Graphic Design course are:

- Students have knowledge of graphic design theories and are able to make vectorbased images

- Students are able to process images based on bitmaps

- Students are able to carry out the process of producing graphic design results using printing equipment.

The Graphic Design course is a Subject in Expertise (MKBK) in the Informatics Engineering Education Study Program Department of Electronics Engineering Faculty of Engineering, State University of Padang.

One of the indications of the low quality of education in Indonesia can be seen from the average learning outcomes that are still low [2]. So, the efforts are needed to improve learning outcomes. The way to improve learning outcomes is to use learning media.

The use of instructional media based on android needs to be done to overcome the conditions of education in Indonesia that have not yet reached the best conditions from other countries [3]. The Indonesian people must have correct habit to use Android technology in a daily activity. If it does not used to develop education it will affect to the level of education in Indonesia.

In general, media of education has utility to overcome various obstacles, such as: communication barriers, limitations of the classroom, the passive students' attitude, students' observations are not uniform and so forth.

Instructional media based on Android is very appropriate to attract the attention of students in learning, because at this time, smartphones have been the most desirable 
gadget or device by various groups, especially for teenagers and students. Besides that, instructional media based on Android can be easy for students which they are not carrying thick books anymore, because of the Android application can be accessed with only one device that can be taken anywhere and can be seen at any time.

\section{$2 \quad$ Literature Review}

Media is a thing that can be used to send messages from the sender to the recipient. Media is very important to be used in teaching and learning, it is hoped that it can help educators in delivering subject matter by using media. Lecturers must be able to be wiser and more precise in choosing the media used. Electronic media is more effective than others, such as: Computers, radios, OHP and others. This media can also be used only in certain places, such as in areas where there is already electricity. In rural areas where there is no electricity, the solution can be used manually and simple media.

Graphic design is defined as "the application of art and communication skills for business and industrial needs"[4]. These applications can include advertising and selling products, creating a visual identity for institutions, products and companies, and a graphical environment, designing information, and visually perfecting messages in publications[5], [6].

Many fields of work are influenced by developments in computer technology. One area of influence is in the field of graphic design. Graphic design is very important because it is used by various groups such as: government, social organizations, military, banks, medicine, education, transportation, trade, crime, industry, and in almost all aspects of life.

Learning media is a tool used for learning needs in an effort to improve learning outcomes [7]. There are various types of learning media, including visual, audio and multimedia media [8]

"The term medium as an intermediary which delivers information between source and recipient"[9]. So, television, films, photos, radio, audio recordings, projected images, printed materials, and the like are communication media. If the media carries out messages or information that has instructional purposes or contains teaching purposes, then the media is called learning media.

Learning Media Development is a technological advance that facilitates educators and students to manage and implement learning. Learning that uses technology cannot be separated from creativity to create interesting learning and easy to understand it. [10].The following explanation of the learning media 1) Media that is not projected (non-projected media), for example: reality, models, graphic material (graphical material), displays. 2) Projected media, for example: OHT, Slide, Opaque. 3) Media audio (audio) tapes, for example: vision, active audio vision. 4) Video media (video). 5) Computer based media (computer-based media), for example: Computer Assisted Instruction (CAI).

Graphic Design is a course about the use of applications to design a product using a laptop or computer to produce interesting drawings and designs for processing[11]. Design is an aesthetic design method based on creativity, while graphics is the science of 
designing points and lines so that it will form an image that can provide information and relate to the printing process. Graphic design is a form of visual communication that uses images as a medium to convey messages or information as effectively as possible. Graphic design is also a science that relies on creativity to create a design in the form of images with the ultimate goal of being of interest in printing. Graphic design was initially applied to static media, such as books, magazines and brochures. In addition, in line with the times, graphic design is also applied in electronic media, which is often referred to as interactive design or multimedia design. The boundaries of the dimensions have also changed with the development of thinking about design. Graphic design can be applied into an environmental design that includes processing space.

Android is an operating system for Linux-based cellular phones as the kernel. Currently Android can be called the king of smartphones. Android is experiencing very rapid development because Android provides an open platform (Open Source) for developers to create their own applications.

Google provides a lot of convenience for developers of software of third parties, such as plug-in Android Development Tools (ADT) for Eclipse (and also tool standalone) includes the ability to logging in real time, realistic emulator that runs the ARM code natively and reporting errors.

Android is a technological advance in the field of software, which is able to operate like a commuter. Android technology has been widely used by consumers for various activities including learning. Android technology development is expected to be utilized as well as possible as an aid in the application of learning media that is simple and interesting to learn.

\section{$3 \quad$ Methodology / Materials}

\subsection{Type of research}

This research is a Research and Development. This study uses a development research design with 4D development media consisting of 4 main stages, namely, Define, Design, Develop, and Disseminate.

\subsection{Sample}

The sample of this research is the students majoring in electronics engineering in the informatics engineering education study program with a total of 30 students. Research samples of semester 1 students taking graphic design courses. The sampling technique uses simple random sampling.

\subsection{Development procedures}

The procedure used for the development of graphic technology learning media based on android is 4D. The following are the stages of the development procedure using 4D: 


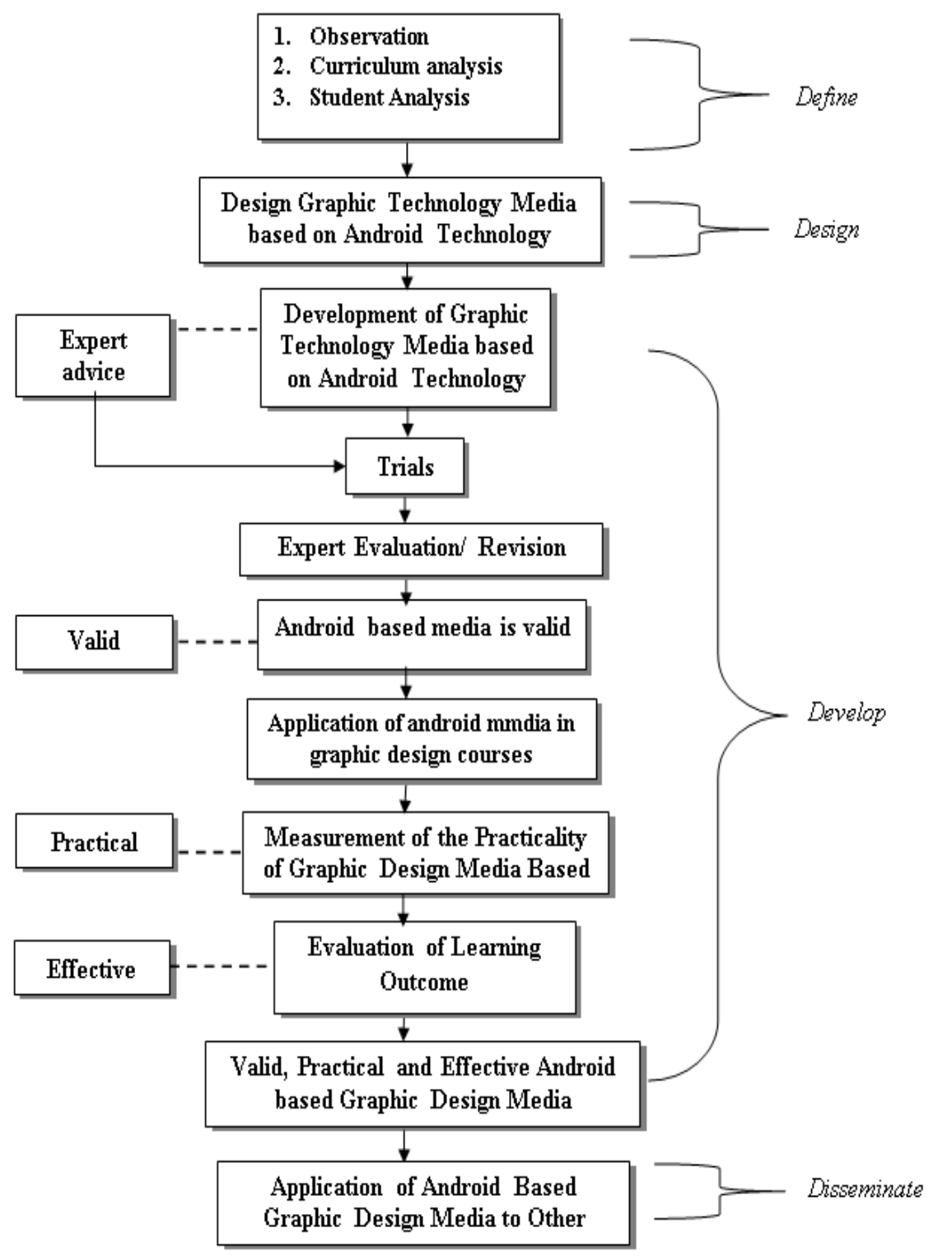

Fig. 1. The procedure for developing a Graphic Design Media is a modified 4-D model. Source: [12], [13]

The development begins with define through observation, curriculum analysis and students, where some problems are obtained and the need for the development of learning media graphics design based on Android technology. After designing and developing and testing on experts and research samples, so we get a practical and effective media. Finally, the distribution was carried out in other classes that studied graphic design courses. 


\subsection{Research instruments}

The instrument used as a practicality questionnaire uses a Likert scale. The test questions are used to obtain the pretest and posttest scores to determine effectiveness. The question before it is carried out in the field is to evaluate the reliability and validity. Based on assessment obtained valid and reliable questions to be applied.

Practicality assessment is given an instrument of assessment to students and effectiveness is given questions to students to assess before using the media (pretest) and after using the media (posttest). Value calculations are analyzed using the SPSS application. The evaluation criteria are carried out by looking at the results of significance > 0.05 , then categorized as practical and effective.

\section{$4 \quad$ Results and Findings}

Based on the results of the study obtained data according to lecturers of Graphic Design courses in the Informatics Engineering Education Study Program, Department of Electronics Engineering, Faculty of Engineering UNP, that there has been a decline in the quality of inputs from the past years. Usually the number of students coming from vocational high schools (Department of Computer Networking, Multimedia and Electronics Engineering) is almost equal to students coming from high school equivalents.

Researchers analyze / study the characteristics of students is to know the general abilities of students, how to learn and how to solve problems, habits / hobbies of students, the environment, language and the use of letters in books that are easily understood by students. The results of the characteristics of these students provide an overview of product design and content coverage in the product support system, especially in the media learning graphic design based on Android. Thus, the product is developed in accordance with the character of the student, so the product can facilitate students such as language that is easily understood, use of letters, placement of materials, sample questions and practice test questions that disturb their curiosity. It is also used as a basis in developing student abilities.

Students are lazy to buy books that are recommended and tend to await explanations from lecturers. Students are more happy if the lecturers explain a subject clearly and copy the lecturer's explanation. In solving graphic design problems in the classroom, it was seen that the fighting spirit of the students was weak and some students even preferred copying / copying the work of their friends who had already made it.

There are disadvantages if students rely solely on lecturers' explanations in front of the class, that is, if the lecturer has to explain difficult problems with a long solution such as explaining graphic design concepts and using graphic design applications that use various tools as tools to design drawings. Sometimes only one or two questions can be explained for one meeting, and even then, it has not been well captured by students.

The presence of the internet as a learning resource, can help students to construct Graphic Design material both independently and in groups. It's just that it seems like students haven't been accustomed to using the internet as a source of graphic design learning. Though a lot of writings about Graphic Design, both written by experts and by students circulating on the internet. 
Based on the pretest research data on Android-based graphic design learning students of Informatics Engineering Education study programs achieved by students after being given a test with a sample of 30 respondents obtained a minimum score range of 0 and a maximum of 100 . Based on the calculations it appears that the number of respondents who obtained an average score of score of learning outcomes Graphic Design (Pretest) respondents who score below the average price, and respondents who score above the average price.

\subsection{Practical assessment of learning media for graphic design based on Android technology}

The results of filling out the practicality questionnaire filled out by students regarding the practicality of Android Technology-Based Graphic Design Learning Media can be seen in Table 1 below:

Table 1. Results of the Practicality Assessment of Learning Media Graphic Design Based on Android Technology

\begin{tabular}{|c|l|c|c|c|}
\hline \multirow{2}{*}{ No } & \multicolumn{1}{|c|}{ Assessment Aspects } & \multicolumn{3}{c|}{ Rating result } \\
\cline { 3 - 5 } & \multicolumn{1}{|c|}{$\begin{array}{c}\text { Average } \\
\text { TCR }\end{array}$} & \multicolumn{1}{c|}{ Category } \\
\hline 1 & $\begin{array}{l}\text { I like to follow the learning process with the modules pro- } \\
\text { vided }\end{array}$ & 4.5 & 90.00 & Very good \\
\hline 2 & The module I read is interesting & 4.2 & 84.00 & Well \\
\hline 3 & The material I read is easy to understand & 4.3 & 86.00 & Well \\
\hline 4 & $\begin{array}{l}\text { This teaching material helped me understand the learning } \\
\text { material }\end{array}$ & 4.2 & 84.00 & Well \\
\hline 5 & This teaching material helps me in the learning process & 4.3 & 86.00 & Very good \\
\hline 6 & The media and methods used are interesting and fun & 4.0 & 80.00 & Well \\
\hline 7 & $\begin{array}{l}\text { The time available is enough to understand the learning pro- } \\
\text { cess }\end{array}$ & 4.5 & 90.00 & Well \\
\hline 8 & $\begin{array}{l}\text { I am interested in participating in such learning in other } \\
\text { learning activities }\end{array}$ & 4.0 & 80.00 & Well \\
\hline & Average & 4.25 & 85.00 & Well \\
\hline
\end{tabular}

Based on Table 1 it can be concluded that the average assessment of the Design graphics instructional media practicality based on Android by students is 4.25 with an achievement level of 85.00 and is in good (practical) criteria. This means that the practicality of the Design graphics instructional media practicality based on Android can be applied. Based on the results of research that conducted in research on android-based static and dynamic electricity learning media it is stated that static and dynamic electricity learning media is easy or practical to use by teachers and students[14].

\subsection{Effectiveness in developing learning media graphic design based on android technology on student learning outcomes.}

Results between after and before media treatment, there was an increase in the level of achievement of student learning outcomes in Graphic Design learning by $50.97 \%$. In the first trial (Pretest), students get an average grade of 53.60 while in the second 
trial (Posttest) the average score of Posttest students is 79.03. while the difference in score (gain score) pretest and posttest is 25.43 . The increase in the value of Pretest and Posttest can be seen in the following graph:

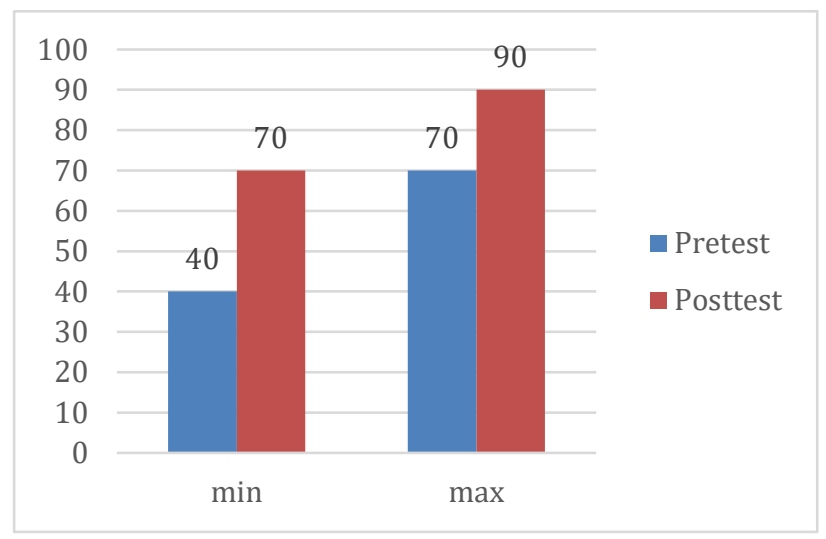

Fig. 2. .Graph of Increase in Value Before and After media treatment

Based on Figure 2 the students' scores at the pre-test and initial post-test with the lowest value of 40 and the highest 70 . When the second test obtained higher results reached a value of 90 . This shows the learning outcomes of students using learning media android technology-based graphic design has increased.

Research hypothesis testing is done by t test analysis. $\mathrm{T}$ test analysis can be done if the analyzed data meet several requirements, namely:

- Data with normal distribution

- Data from homogeneous populations.

To see whether these requirements can be met or not, it is necessary to test the requirements analysis. From the results of data processing through the KolmogorovSmirnov normality test, the normality of data distribution is obtained as shown in the following table:

Table 2. Data Normality Test Results

\begin{tabular}{|l|c|c|c|}
\hline \multirow{2}{*}{\multicolumn{1}{c|}{ Variable }} & \multicolumn{3}{c|}{ Kolmogorov-Smirnov } \\
\cline { 2 - 4 } & Statistics & $\boldsymbol{N}$ & Sig. \\
\hline Learning Outcomes (Pretest) & .106 & 30 & .200 \\
\hline Learning Outcomes (Posttest) & .143 & 30 & .119 \\
\hline
\end{tabular}

Based on Table 2 it is known that the significance value for the Learning Outcomes variable (Pretest) is $0.200>0.05$ which means that the frequency distribution of the learning outcome variable data (Pretest) is normal. Furthermore, the test of the normality of the learning outcomes variable (Posttest) obtained a significance of $0.119>0.05$, which means the learning outcome variable data (Posttest) is normally distributed. 
Based on the description above, all data collected on each study variable has a normal distribution. This means that the distribution of respondents' answers has fulfilled the normality assumption so that it can be used in further testing.

Homogeneity test is done to see whether the research data has the same variance (homogeneous) or not. The results of data analysis obtained homogeneity in Table 3 as follows:

Table 3. Data Homogeneity Test Results

\begin{tabular}{|c|c|c|c|c|c|}
\hline Variable Research & Levene Statistics & Df1 & Df2 & Sig. & Information \\
\hline Learning Outcomes (Pretest) & 1.653 & 6 & 18 & 0.190 & Homogeneous \\
\hline Learning Outcomes (Posttest) & 1.648 & 8 & 17 & 0.184 & Homogeneous \\
\hline
\end{tabular}

The analysis results above show that the probability significance value for each variable is greater than 0.05 , thus meaning that the data of this study are homogeneous, so it can be continued for hypothesis testing analysis.

Hypothesis testing is done by using a t-test of student learning outcomes before (Pretest) and after (Posttest) media treatment.

Table 4. Distribution of Average Results (Pretest) with (Posttest)

\begin{tabular}{|l|l|l|l|l|l|}
\hline \multicolumn{1}{|c|}{ Variable } & The mean & Elementary school & \multicolumn{1}{c|}{ SE } & Sig. & N \\
\hline Student Learning Outcomes & & & & & \\
-Pretest & 53.60 & 8,811 & 1,609 & 0,000 & 30 \\
-Posttest & 79.03 & 5,014 & 0.915 & 0,00 \\
\hline
\end{tabular}

Source: Primary data processing 2015

Based on Table 4 the average student learning outcomes (pretest) was 41.40 with a standard deviation of 6.173 . The average posttest student learning outcomes are 60.60 with a standard deviation of 6.350. The mean difference between Student Learning Outcomes before being given the media (Pretest) and student learning outcomes after being given the media (Posttest) is 19.20 with a standard deviation of 9.197. Statistical test results obtained $p=0.000$, so it can be concluded that there are differences in student learning outcomes before being given the media (Pretest) with student learning outcomes after being given the media (Posttest).

Table 5. T-Test Student Learning Outcomes before media treatment (Pretest) with student learning outcomes after media treatment (Posttest)

\begin{tabular}{|l|c|c|c|c|c|}
\hline \multicolumn{1}{|c|}{ Variable } & The mean & Elementary school & SE & t & Sig. \\
\hline $\begin{array}{l}\text { Student Learning Outcomes } \\
\text { Posttest -Pretest }\end{array}$ & 25,433 & 14,662 & 1,851 & 13,742 & 0,000 \\
\hline
\end{tabular}

Source: Primary data processing 2015

From the results of the $t$ test above it can be seen that the $t$-value $=13.742>t$-table $=1.70$ at a significant level $\alpha=0,000$ it means that $\mathrm{H} 0$ is rejected and $\mathrm{H} 1$ is accepted, thus the hypothesis stating there are differences in Student Learning Outcomes before media treatment (Pretest) with student learning outcomes after media treatment (Posttest) can be accepted. This is also indicated by the significant level of $0,000<0.05$, which means that there are significant differences between Student Learning Outcomes 
before media treatment (Pretest) and student learning outcomes after media treatment (Posttest).

The results of calculations based on android-based media development research showed an increase in the ability of students in the experimental class and the control class [15]. The results of the learning assessment carried out get the conclusion of learning using android-based media can increase student learning independence.

The instrument used as a practicality questionnaire uses a Likert scale. The test questions are used to obtain the pretest and posttest scores to determine effectiveness. The question before it is carried out in the field is to evaluate the reliability and validity. Based on assessment obtained valid and reliable questions to be applied.

Practicality assessment is given an instrument of assessment to students and effectiveness is given questions to students to assess before using the media (pretest) and after using the media (posttest). Value calculations are analyzed using the SPSS application. The evaluation criteria are carried out by looking at the results of significance > 0.05 , then categorized as practical and effective.

\section{Conclusion}

Producing a Graphic Design learning media based on Android that is practical and effective to support the learning process of Graphic Design. Development of Graphic Design learning media based on Android in the practicality and effectiveness test stage shows that the product has met the practicality and effectiveness criteria.

This development is through the 4-D model design process which consists of four stage:

- Define

- Design

- Develop

- Disseminate phase

The results of the development of Learning Technology Graphic Design Media Based on Android Technology were obtained from lecturers who acted as managers, facilitators and motivators, the existence of collaborative processes to help each other in understanding the material concepts by students, the attitude of individual student responsibility.

Learning Media Graphic Design Based on Android was effective to improve student learning outcomes individually. The effectiveness of the use of this media compared to the previous media was different due to many factors, including: student involvement and lecturer guidance. Student involvement and lecturer guidance in the learning process using Android media is higher than the previous media. Lecturers as managers of the learning process create an atmosphere of active student learning by preparing graphic design learning media based on Android and students mastering teaching material, and evaluating learning outcomes.

The effectiveness of the Android-based graphic design learning media is also determined by the initial abilities and study skills possessed by students. Students who 
have high initial ability and study skills will understand the subject matter faster than students who have low initial ability and study skills. Thus, in the application of Android-based learning media models need to pay attention to students' initial abilities and provide effective study skills so that they can be used in completing the learning tasks they face.

\section{$6 \quad$ References}

[1] Mukhidin, Kurikulum dan Pembelajaran Kejuruan Berbasis Kompetensi. Bandung: Rizki Press, 2012.

[2] S. Akhmad, "Pembelajaran Tuntas," 2009. [Online]. Available: http://akhmadsudrajat.wordpress.com/2009/11/02/pembelajaran-tuntas-mastery-learning-dalam-ktsp/ [Accessed: 28-Oct-2013].

[3] I. A. D. Astuti, D. Dasmo, and R. A. Sumarni, "Pengembangan Media Pembelajaran Berbasis Android dengan Menggunakan Aplikasi Appypie di SMK Bina Mandiri Depok," J. Pengabdi. Kpd. Masy., 2018. https://doi.org/10.24114/jpkm.v24i2.10525

[4] M. Suyanto, Multimedia alat untuk meningkatkan keungulan bersaing. Yogyakarta: Andi Offset, 2005.

[5] H. Hendi, The Magic of Corel Draw. Bandung: Informatika, 2009.

[6] H. Hendi, The Magic of Macromedia Director. Bandung: Informatika, 2010.

[7] R. Susilana and Dkk, Kurikulum Pembelajaran. FIP: Universitas Pendidikan Indonesia, 2006.

[8] Gintings Abdorrakhman, Esensi Praktis Belajar dan Pembelajaran. Bandung: Humaniora, 2010.

[9] A. Arsyad, Media Pembelajaran. Jakarta: PT. Raja Grafindo Persada, 2010.

[10] K. Cecep, \&, and S. Bambang, Media Pembelajaran Manual dan Digital. Jakarta: Ghalia Indonesia, 2011.

[11] H. Hendi, Tips and Trix Computer Graphics Design. Bandung: Informatika, 2008.

[12] S. Thiagarajan, D. S. Semmel, and M. I. Semmel, Instructional Development for Training Teachers of Exceptional Children. Minneapolis. Minnesota: Leadership Training Institute/Special Education, University of Minnesota, 1947.

[13] Trianto, Model Pembelajaran Terpadu. Jakarta: Bumni Aksara, 2010.

[14] A. Z. Mahesi, E. W. Rizky, I. Syaiful, and P. Doni, "Designing Static And Dynamic Electrical Learning Media Based on Android,” J. Inf. Technol. Comput. Sci., vol. 1, no. 1, p. e-ISSN : 2614-1574, 2018.

[15] P. Hendikawati, M. Zuhair, and R. Arifudin, "Keefektifitas Media Pembelajaran Berbasis Android terhadap Kemampuan Pemecahan Masalah dan Kemandirian Belajar," Prisma, 2019.

\section{Authors}

Dr. Asrul Huda is currently working at,UniversitasNegeri Padang. Indonesia, as a Senior Lecturer. Experienced in Technical Vocational Education and Training, especially in Electrical Engineering, since 2010 until now. Currently has a degree of Doctorate in UniversitasNegeri Padang. Indonesia. Research interest includes TVET, Multimedia Graphic Design, Educational research. Having 17 Publications in Journals. 
Completed 12 projects and has a vast experience in the field of Multimedia and graphic design. asrulhuda@gmail.com

Mrs. Nelda Azhar currently works at Universitas Negeri Padang. Indonesia, as a Senior Lecturer. Experienced in Technical Vocational Education and Training, especially Electronics Engineering, since 1984 until now. Currently has a Masters degree at Universitas Negeri Padang. Indonesia. Research interests include TVET, Engineering Physics, Educational Research. Has 18 publications in the Journal. Completed 15 projects and had extensive experience in the fields of Engineering Physics, and Electronic Electrical Engineering. neldaazhar@yahoo.co.id

Mr. Almasri currently works at Universitas Negeri Padang. Indonesia, as a Senior Lecturer. Experienced in Vocational Engineering Education and Training, especially Electrical Engineering, since 1988 until now. Currently has a master's degree at Universitas Negeri Padang. Indonesia. Research interests include TVET, Electrical Electronics Engineering, Microcontrollers, control systems, Educational Research. Has 21 publications in the Journal. Completed 10 projects and had extensive experience in the field of Control Systems. al_unp@yahoo.co.id

Mr. Suryo Hartanto currently working at Universitas Riau Kepulauan. Indonesia, as a Senior Lecturer. Experienced in Technical Vocational Education and Training, especially in mechanical engineering since 2009 until now. Currently has a degree of Master and Doctorate in Technical Vocational Education and Training of UniversitasNegeri Padang. Indonesia. Research interest includes: teacher and training in higher education, TVET. Having 20 Publications in Journals. Completed 9 projects supported by Research, Technology, and Higher Education of the Republic of Indonesia and has a vast experience in the field of vocational education. tsuryohartanto@yahoo.com

Mr. Khairul Anshari is holds a master's degree in the field of education the concentration of electronics engineering education by Padang State University, Technology and Vocational Education, Indonesia. He has taught courses since 2017 in computer technology. anshari_khairul@yahoo.co.id

Article submitted 2019-11-29. Resubmitted 2019-12-28. Final acceptance 2020-01-07. Final version published as submitted by the authors. 